\title{
Religie en globale bio-etiek: Religieuse globale bio-etiek as voorloper tot 'n universele bio-etiek
}

\begin{tabular}{|c|c|}
\hline \multicolumn{2}{|c|}{$\begin{array}{l}\text { Author: } \\
\text { Riaan Rheeder }\end{array}$} \\
\hline \multicolumn{2}{|c|}{$\begin{array}{l}\text { Affiliation: } \\
{ }^{1} \text { Faculty of Theology, } \\
\text { North-West University, } \\
\text { Potchefstroom Campus, } \\
\text { South Africa }\end{array}$} \\
\hline \multicolumn{2}{|c|}{$\begin{array}{l}\text { Note: } \\
\text { The article is a reworked } \\
\text { version of an published } \\
\text { article Religion and global } \\
\text { bioethics, in the Encyclopedia } \\
\text { of Global Bioethics, } \\
\text { December 2014, available } \\
\text { from http://link.springer. } \\
\text { com//10.1007/978-3-319- } \\
\text { 05544-2_365-1 }\end{array}$} \\
\hline \multicolumn{2}{|c|}{$\begin{array}{l}\text { Correspondence to: } \\
\text { Riaan Rheeder }\end{array}$} \\
\hline \multicolumn{2}{|c|}{$\begin{array}{l}\text { Email: } \\
\text { riaan.rheeder@nwu.ac.za }\end{array}$} \\
\hline \multicolumn{2}{|c|}{$\begin{array}{l}\text { Postal address: } \\
\text { PO Box 62, Potchefstroom, } \\
2520 \text {, South Africa }\end{array}$} \\
\hline \multicolumn{2}{|c|}{$\begin{array}{l}\text { Dates: } \\
\text { Received: } 13 \text { Oct. } 2014 \\
\text { Accepted: } 22 \text { May } 2015 \\
\text { Published: } 24 \text { Aug. } 2015\end{array}$} \\
\hline \multicolumn{2}{|c|}{$\begin{array}{l}\text { How to cite this article: } \\
\text { Rheeder, R., 2015, 'Religie en } \\
\text { globale bio-etiek: Religieuse } \\
\text { globale bio-etiek as voorloper } \\
\text { tot 'n universele bio-etiek', } \\
\text { HTS Teologiese Studies/ } \\
\text { Theological Studies 71(3), } \\
\text { Art. \#2842, } 9 \text { pages. http:// } \\
\text { dx.doi.org/10.4102/hts. } \\
\text { v71i3.2842 }\end{array}$} \\
\hline \multicolumn{2}{|c|}{$\begin{array}{l}\text { Copyright: } \\
\text { C 2015. The Authors. } \\
\text { Licensee: AOSIS } \\
\text { OpenJournals. This work is } \\
\text { licensed under the Creative } \\
\text { Commons Attribution } \\
\text { License. }\end{array}$} \\
\hline \multirow{2}{*}{$\begin{array}{l}\text { Read online: } \\
\text { 口idita }\end{array}$} & \\
\hline & $\begin{array}{l}\text { Scan this QR } \\
\text { code with your } \\
\text { smart phone or } \\
\text { mobile device } \\
\text { to read online. }\end{array}$ \\
\hline
\end{tabular}

Religion and global bioethics: Religious global bioethics as a precursor to a universal bioethics. From a general public perspective, this article presumes that there is such a thing as a universal ethics; however this assumption does not decrease the challenges with regard to a 'global ethics' and 'bioethics'. The article discusses the views on global religious bioethics that were formulated in 1999. The article further considers these formulations as the forerunner of UNESCO's perspective on universal bioethics accepted in 2005. The article aims to argue that a global value system will enhance hope of peace and justice in today's global world. It argues that the absence of shared ethics will reinforce conflict between civilisations and worsen injustice.

\section{Inleiding}

In sy boek Hope for a global ethic betoog Lepard (2011) dat die religieus gemotiveerde 9/11 (2001)-aanval op Amerika opnuut die vraag van 'n globale etiek na vore gebring het, maar is hy van mening dat 'n globale etiek tans nog net 'n moontlikheid is. In aansluiting hierby is Nezhmetdinova (2013:83-85) van mening dat, alhoewel bio-etiek 'n globale verskynsel is, daar nog steeds 'a search for a unified human platform to solve the global problems' is.

Uit 'n ander hoek wys Ten Have and Gordijn (2014) in 'n artikel oor globale bio-etiek daarop dat sommige wetenskaplikes van opinie is dat die aanspraak op 'n normatiewe universaliteit binne die veld van bio-etiek (en godsdiens) ongesubstansieer is (vgl. ook Gracia 2014). Op sy beste kan gesê word dat 'n Westerse bio-etiek na die res van die wêreld uitgevoer is en dus niks meer as 'n imperialistiese afdwing van etiese waardes op die globale gemeenskap is nie. Amerikaanse bioetici soos Albert Jonsen en Dan Callahan redeneer dat bio-etiek 'n Amerikaanse produk is, omdat dit ' $n$ Amerikaanse uitvindsel is en intiem met die Amerikaanse etos vervleg is (Jonsen 1998:377; Callahan 1973:66-73). In hulle argumentasie verwys Ten Have en Gordijn (2014) na drie artikels wat onlangs in die boek Bioethics around the Globe (Myser 2011) verskyn het waarin akademici uit die ontwikkelende en Eerstewêreldomgewing universele bio-etiek as 'n 'story of exportation' van Westerse waardes beoordeel. In die lig van hierdie perspektiewe kan daar nie werklik iets soos globale bio-etiek bestaan nie en is universele bio-etiek bloot ' $n$ verspreiding van Westerse bioetiek. In hierdie sin is bio-etiek in die res van die wêreld slegs Amerikaanse waardes wat volgens die idiosinkrasie van die nie-Amerikaanse lande aangepas is.

Akademici wat binne bogenoemde perspektiewe dink en beweeg se klem val hoofsaaklik op die enorme kulturele diversiteit. Antropoloë lê besondere klem op die kulturele diversiteit van etiese norme, wat noodwendig etiese relativisme beteken, en daarom is gedeelde waardes nie moontlik nie (Gracia 2014:29). Bio-etiek moet altyd 'n plaaslike oorsprong en 'n plaaslike veld van toepassing hê. 'n Bio-etiek vir Suid-Afrika kan dus slegs in Suid-Afrika onstaan en in Suid-Afrika toegepas word. Enige vorm van etiese riglyne van buite 'n plaaslike leefmilieu is noodwendig Westerse waarde-imperialisme wat nie-Westerse tradisies minag en daarom beledigend en ongewens is. Aan die anderkant is globale bio-etiek vir die Westerse persoon onnodig en onmoontlik (Ten Have \& Gordijn 2014:4-5).

Die probleemstelling van hierdie artikel kan met die volgende stelling van Ten Have en Gordijn (2014:5) weergegee word: 'Global bioethics in this perspective will primarily address different traditions, religions, and cultures, but is less interested in the question what they have in common.'

In die lig van bogenoemde verduideliking onstaan die volgende vrae: Eerstens, is globale (religieuse) waardes en beginsels wat deur alle mense gedeel word 'n moontlikheid of 'n realiteit? Tweedens, is 'n globale bio-etiek moontlik wat internasionaal en transkultureel is en nie van Westerse etos verdink word nie? Laastens, bestaan daar enige direkte of indirekte verband tussen globale godsdienstige waardes en 'n globale bio-etiek? (Gracia 2014:29; Ten Have \& Gordijn 2014:11) 
Hierdie vrae is nie net om akademiese redes belangrik nie, maar het definitiewe praktiese ramifikasies. Indien 'n globale etiek geïdentifiseer kan word, kan so 'n waardestelsel as 'n gemeenskaplike grond dien vir 'n vreedsame benadering tot opkomende politiese, ekonomiese, tegnologiese en omgewingsprobleme. Aan die anderkant, as die hoop op 'n globale etiek ' $n$ blote illusie is, is die kanse op 'n vreedsame oplossing vir globale probleme uiters skraal. In 'n globale wêreld sal'n globale waardestelsel die hoop op vrede verhoog, terwyl die afwesigheid van ' $n$ gedeelde etiek die botsing van beskawings tot gevolg sal hê (Hollenbach 2003:232).

\section{Globale etiek \\ Inleidend}

As antwoord op bogenoemde probleemstelling is Gracia (2014:29) en Ten Have en Gordijn (2014:13), van mening dat die godsdienste van die wêreld reeds aangetoon het dat ' $n$ globale etiek wel moontlik is. In 'n sekere sin kan die bewering gemaak word dat die godsdienste van die wêreld onregstreeks die voorbereiding en geestelike klimaat help skep het vir die ontstaan van 'n globale bio-etiek.

Onder 'globale etiek' word 'n noodsaaklike minimum van gedeelde menslike waardes, kriteria en welwillendheid verstaan (Ten Have \& Gordijn 2014:13). Daar moet erken word dat daar nie net baie groot verskille tussen godsdienste is nie, maar ook tussen vorme van lewe, wetenskaplike sieninge, ekonomiese stelsels, sosiale modelle en geloofsgemeenskappe, wat veroorsaak dat 'n totaal etiese konsensus onmoontlik is (Küng 1997).

\section{Globale etiek se bevraagtekening}

Baie wetenskaplikes is wantrouig teenoor universele etiese riglyne wat kulturele verskille wil transendeer (Ten Have \& Gordijn 2014:12). Daar is sommige persone wat van mening is dat etiese konsensus tussen godsdienste onmoontlik is, aangesien daar net te veel dogmatiese verskille en struikelblokke is om etiese konsensus tussen godsdienste te vind en dit word telkens ervaar dat goeie verhoudinge tussen godsdienste gereeld deur elke moontlike vorm van dogmatisme geblokkeer word. In die lig van die verskille tussen godsdienste, godsdienstige selfhandhawing en fundamentalisme moet etiese konsensus as 'n mooi illusie afgemaak word (Küng 1997:91-92).

In sy artikel The clash of civilizations is die bekende politieke analis, Samuel P. Huntington (1993:22), van mening dat verskillende kulture en godsdienste nie anders kan as om met mekaar in konflik te wees nie. Godsdienste se onderskeie geloofsinhoude en morele waardes is in beginsel onversoenbaar en kan daarom slegs tot voortdurende, geweldige konfrontasie lei (Gracia 2014:23-24; Küng 1997:92). Die wêreldbekende bio-etikus, H. Tristram Engelhardt jr., is van mening dat konsensus in 'n postmoderne wêreld onmoontlik is en dat 'n globale (bio-)etiek dus nie haalbaar is nie (Engelhardt 2006:3, 6). Die vraag word gevra of gedeelde waardes tussen alle mense inderdaad moontlik is:
Anthropologists are aware of the diversity of moral norms in different cultural and religious traditions. They assume generally as a postulate the so-called 'cultural relativism' also in the moral domain ... Could it be possible, then, to formulate some universal moral principles? Are there some moral contents that can be called global? (bl. Gracia 2014: 29; Ten Have \& Gordijn 2014:11-12)

\section{Globale etiek se moontlikheid}

Die uitgangspunt van hierdie artikel is dat gedeelde waarheid nie net ' $n$ teoretiese moontlikheid nie, maar'n onweerlegbare werklikheid is.

Eerstens kan daarop gewys word dat gedeelde waardes nie net ' $n$ teoretiese werklikheid nie, maar 'n aantoonbare antropologiese verskynsel is. Michael Walzer (1994:1-19) het daarop gewys dat daar in politieke konflik 'n universele element waargeneem kan word. Sy navorsing wys daarop dat mense regoor die wêreld, ongeag die grense van nasie, kultuur en godsdiens, spontaan weet watter waardes en kriteria in konflik oortree word. Walzer (1994:3) merk op dat dit vir hom en ander duidelik geword het dat daar in konflik 'n 'easy friendliness and agreement' met betrekking tot waarheid en geregtigheid waargeneem kan word. 'n Stelsel soos apartheid het getoon dat tallose mans en vrouens wêreldwyd, ongeag nasionaliteit, kultuur of godsdiens, met verontregte mense kon identifiseer en spontaan solidariteit betoon. Die rede daarvoor was die feit dat almal met moeitelose vriendelikheid kon saamstem oor byvoorbeeld die byna ongedefinieerde waardes van waarheid en geregtigheid. Mense wat teen hierdie brutaliteit betoog, doen dit nie op grond van enige (godsdienstige) teorie oor geregtigheid nie, maar op grond van 'n gemeenskaplike wete (sommige godsdienstige tradisies omskryf dit as die natuurwet) dat sulke optrede nie reg is nie. Mense verenig in gees met betogers op grond van 'n gedeelde, ongedefinieerde waarde, of weet dat iets reg of verkeerd is (Twiss 2011:212). Wanneer mense wel amptelik bymekaar kom, kan hierdie gedeelde waardes as 'core morality' of elementêre etiese standaarde geformuleer word en in bogenoemde geval, beskou word as die uitvoering van basiese geregtigheid. Hierdie kernbeginsel ('thin morality') word dan vanuit die onderskeie kulture en godsdienstige agtergronde ('thick morality') begrond en aangevul (Küng 1997:94-95).

Tweedens is gedeelde waardes ook ' $n$ historiese werklikheid. In 1893 is ' $n$ tradisie nie-amptelik in Chicago gebore, naamlik die 'Parliament of the World's Religions' (PWR), waar verteenwoordigers van alle godsdienste en spirituele oortuigings deur middel van hulle leiers, geleerdes, teoloë en belangstellendes bymekaargekom en saam oor die plek van geloof en spiritualiteit in die kontemporêre wêreld gedink het. Hierdie was die eerste formele globale byeenkoms van godsdienste van die wêreld, maar was ongelukkig Eurosentries van aard en het nie Tibettaanse boeddhiste, Afroen inheemse Amerikaners ingesluit nie (Gensler 2013:57).

In 1993 is bogenoemde 'Parliament of the World's Religions' hergebore met die byeenkoms van 8000 verteenwoordigers 
(nagenoeg 200 leiers van ongeveer 40 verskillende religieuse en spirituele tradisies) van regoor die hele wêreld. Tydens hierdie byeenkoms is daar gesprek gevoer oor die rol van godsdienstige gemeenskappe in die oplossing van probleme in die wêreld. Die byeenkoms was van oortuiging dat samewerking tussen diverse godsdienstige groepe nie anders kan plaasvind as binne 'n konteks van gedeelde waardes nie. Die gevolg was dat die Council for a Parliament of the World's Religions 'n dokument, 'Towards a global ethic: An initial declaration', voorberei en aan die verteenwoordigers voorgelê het. Ten spyte van die feit dat verskeie godsdienste in daardie stadium in bloedige oorloë gewikkel was, het volgelinge van verskeie godsdienste, groot en klein, Oos en Wes, as verteenwoordigers van ontelbare aantal gelowiges op aarde, hierdie historiese verklaring hulle eie gemaak deur dit te onderteken (PWR 1999:3-4 van 15).

Al die godsdienste van die wêreld het gedeelde waardes wat soos volg omskryf kan word: Menslikheid ('humanity') is 'n basiese, etiese vertrekpunt. Uit hierdie vertrekpunt het al die godsdienste van die wêreld twee beginsels aanvaar, naamlik dat elke mens menslik behandel moet word en dat wat jy vir jouself toewens, jy ook aan 'n ander mens moet doen (die bekende goue reël).

Op grond van bogenoemde waardes het die godsdienste van die wêreld vier onherroepelike etiese riglyne geformuleer en aanvaar wat deel van 'n globale godsdienstige etiek vorm. Die eerste riglyn is negatief as 'moenie doodmaak nie' geformuleer en positief as 'respek vir lewe' gestel, wat 'n verpligting tot ' $n$ kultuur van nie-geweld en respek impliseer. Tweedens mag jy nie steel nie, en moet jy eerlik en billik sake doen, wat 'n kultuur van solidariteit en 'n regverdige ekonomiese orde behels. Derdens mag 'n mens geen leuens vertel nie, maar moet jy die waarheid praat en eerbaar optree, wat 'n kultuur van verdraagsaamheid en 'n lewe van betroubaarheid inhou. Laastens mag 'n mens geen seksuele immoraliteit pleeg nie en moet mense mekaar respekteer en liefhê, wat 'n kultuur van gelyke regte en 'n vennootskap tussen mans en vrouens beteken (PWR 1999:4; Gracia 2014:24; Küng 1997:108, 110111). Die bewering kan gemaak word dat daar reeds uit die 'Global Ethic' afgelei kan word dat bogenoemde etiese beginsels ook bedoel is om as moontlike riglyne vir 'n globale bio-etiek gebruik te word (PWR 1993):

A universal consensus on many disputed ethical questions (from bio- and sexual ethics through mass media and scientific ethics to economic and political ethics) will be difficult to attain. Nevertheless, even for many controversial questions, suitable solutions should be attainable in the spirit of the fundamental principles we have jointly developed here. (bl. 14 van 15)

In aansluiting by bogenoemde het die verbasende gebeur dat die Parliament of the World's Religions die 'Global Ethic' na 'n 'Global Bioethic' uitgebrei het. In 1999 het die Parliament of the World's Religions in Suid-Afrika vergader. Tydens hierdie byeenkoms het die Council for a Parliament of the World's Religions dringend gepleit vir 'n voortgaande refleksie op die etiese verpligtinge soos dit in die 'Global Ethic' voorkom en die strewe na 'n nuwe manier of omgewing om die etiese beginsels toe te pas. Tydens hierdie byeenkoms het die Parliament of the World's Religions 'n opvolgdokument, 'A call to our guiding institutions', opgestel (Gracia 2014:30). Die byeenkoms was van oordeel dat baie sterk instellings ' $n$ groot invloed op mense en die toekoms uitoefen en dat instellings daarom opgeroep word om hulle waardes, perspektiewe en aannames in die lig van die 'Global Ethic' te beoordeel. Die volgende instellings word in die PWR opgeroep: Religie en spiritualiteit, regering, landbou-arbeid-industrie-handel, onderwys, kuns en kommunikasie, wetenskap en medisyne, internasionale tussenregeringsinstellinge en organisasies van die burgerlike gemeenskap.

Die PWR kan as die toepassing en verruiming van die etiese riglyne beskou word soos wat dit in die Global Ethic gevind word en word in die dokument beskryf as 'n 'expression of beliefs and convictions already deeply held — and held in commonby the world's religious and spiritual communities' ( PWR 1999:5 van 37). Uit die PWR is dit duidelik dat die Parliament of the World's Religions, en daarmee die totale godsdienstige wêreld, van oordeel is dat medisyne en wetenskap sonder twyfel etiese uitdagings aan die wêreldgemeenskap stel en wil dit daarom ' $n$ morele visie van 'n beter wêreld binne die bio-etiek aanbied. Hierdie visie word onder die tema van 'The call to the science \& medicine' behandel (PWR 1999:11 van 37). In die dokument word etiek en menseregte met mekaar verbind, terwyl bio-etiese beginsels soos outonomie, ingeligte toestemming, bate, nie-behandeling, respek vir weerloosheid, inagneming van die toekoms, beskerming van die omgewing, solidariteit, sosiale verantwoordelikheid en gesondheid en die deling van voordele as 'n morele visie voorgehou word (PWR 1999). Ter wille van meer duidelikheid word daar direk uit die dokument aangehaal:

- We envision a world in which ... access to knowledge and to the healing arts is not a privilege but a right.

- Researchers and teachers, physicians and engineers, physicists, chemists, and biologists should be committed to benefiting human life and reducing suffering.

- The influence and power of science, medicine, and technology are now so enormous that scientists, physicians, and engineers bear an unprecedented responsibility for the future.

- Not only their knowledge and technical skills, but also their conscientiousness and prudence are critical to what we make of ourselves and our world in the next decades.

- Each is invited ... to resist efforts at control, redirection, or even domination of scientific and medical enterprises by narrowly defined interests, whether economic, political, military, or religious.

- Each is invited ... to give priority, in the development of new programs of research, application, and outreach, to those children, women, and displaced peoples around the world who have little access to advanced systems, tools, and modalities of healing.

- Each is invited ... to take always into account, in the design of experimental protocols, public health programs, laboratories, research centers, clinics, and hospitals, the constellation of values, cultural norms, and spiritual concerns of local communities. 
- Each is invited ... to find ways to focus the creative energies of science and medicine more intentionally, systematically, and intensively on the most pressing issues of human survival, such as food, health, demographic change, and ecological sustainability. (28-29 van 37 )

Dit is interessant dat hierdie godsdienstige 'globale bioetiese' waardes ongeveer ses jaar voor UNESCO se universele deklarasie vir bio-etiek en menseregte geformuleer is. Die bewering kan gemaak word dat die globale godsdienstige wêreld die relevansie van ' $n$ globale bio-etiek besef het en dat hierdie gewaarwording die wêreldgemeenskap voorberei en indirek opgeroep het tot die formulering van 'n globale bioetiek wat op die regerings van die wêreld gerig is, asook op individue, groepe, gemeenskappe, instellings en korporasies.

\section{Globale etiek in konteks}

Watter omstandighede het tot 'n globale etiese diskoers bygedra, asook tot die verwerkliking daarvan? Eerstens kan daar geargumenteer word dat die menseregtediskoers die weg vir die moontlikheid van 'n globale etiese diskoers voorberei, omdat menseregte ook 'n globale visie vertoon (Ten Have \& Gordijn 2014:12).

Tweedens is 'n globale etiek 'n uitvloeisel van globalisasie. Vandag kan die wêreld inderdaad as 'n 'global village' beskryf word. Die filosoof Pierre Teilhard de Chardin (1881-1995) het al voorspel dat die wêreld 'n globale gemeenskap gaan word, nie omdat die mensdom 'n enkele waarheid aanvaar of 'n kulturele eenheid begeer nie, maar omdat die mensdom al hoe meer onder die indruk van 'n gedeelde afhanklikheid en toekoms gekom het. Deur kommunikasie soos radio, televisie en Internet is mense wêreldwyd onderling verbind. Afstande tussen mense het baie kleiner geword en grense tussen nasies het onbeduidend begin word. Dit was nog nooit so maklik om ander mense te ken nie. Hierdie kommunikasie bring 'n groeiende unifikasie binne komplekse diversiteit tot stand, asook 'n groter gevoel van solidariteit tussen mense. Persone van verskillende nasionaliteite, kulture en godsdienste van regoor die wêreld is met mekaar verbind en word besonder bewus van mekaar se omstandighede. Hierdie bewussyn het tot gevolg dat die godsdienstige mensdom onder die indruk van mekaar se enerse humaniteit of gedeelde mensheid gekom het. Mense herken hulle eie menslikheid in ander mense en daarom kan daar met mekaar se vreugde, pyn, lyding, worsteling en essensiële menslike behoeftes geïdentifiseer word (PWR 1999:9 van 37). Mense verstaan ook ander mense se lyding en wil hulle solidariteit daarmee toon. Hierdie gewaarwording het by mense oor die wêreld die besef laat posvat dat gedeelde menswees op sigself 'n gegewe waarde is en dit is die rede waarom daar van onmenslike behandeling of misdaad teen die mensdom gepraat word. Hierdie werklikheid impliseer die moontlikheid van nog meer gedeelde waardes (Gracia 2014:20, 26; Küng 1997:98; Plantinga, Thompson \& Lundberg 2010:1128-1172; Ten Have \& Gordijn 2014:10, 12).
Derdens is 'n globale etiek bereikbaar, omdat daar in die meeste groot godsdienste en filosofiese tradisies identiese etiese materiaal gevind word (Twiss 2011:207). In sy bespreking van die opstel van die 'Global Ethic' wys Küng daarop dat hy aanhalings uit heilige geskrifte vermy het, omdat elke godsdiens 'n besondere teks uit sy geloofstradisie sou wou gebruik, wat tot 'n eindelose aanhaling van tekste en moontlik spanning kon lei. Tog kon godsdienste oor die wêreld saamstem oor die gebruik van een religieuse teks wat in byna alle heilige geskrifte voorkom en dit is die bekende goue reël (Küng 1997:98-99). Küng maak die opmerking dat die goue reël wat so fundamenteel is, ' $n$ indrukwekkende aanduiding is dat' $n$ gemeenskaplike globale etiek nie 'n nuwe uitvindsel is nie, maar slegs 'n nuwe ontdekking (Küng \& Kuschel 1993:71). Om hierdie realiteit meer konkreet aan te dui is dit wenslik om van die goue reëlformulerings aan te haal (vgl. Gensler 2013:76-107):

- Hinduism (ca. 400 BC):

One who regards all creatures as his own self, and behaves towards them as towards his own self, attains happiness. One should never do to another what one regards as hurtful to one's own self. This, in brief, is the rule of righteousness. In happiness and misery, in the agreeable and the disagreeable, one should judge effects as if they came to one's own self (Mahabharata bk. 13: Anusasana Parva § 113). (Gensler 2013:77)

- Jainism (ca. $500 \mathrm{BC}$ ): 'A monk should treat all beings as he himself would be treated (Jaina Sutras, Sutrakritanga, bk. 1, 10: 1-3)' (Gensler 2013: 77).

- Confucius (ca. 551-479 BC): 'Don't do to others what you don't want them to do to you. (Analects 15:23)' (Gensler 2013:76).

- Buddha (ca. 563-483 BC):

There is nothing dearer to man than himself; therefore, as it is the same thing that is dear to you and to others, hurt not others with what pains yourself. (Dhammapada, Northern Canon 5:18). (Gensler 2013:76)

- Rabbi Hillel (ca. 30 BC-10 AD): 'What is hateful to yourself, don't do to another. That is the whole Torah. The rest is commentary. Go and learn. (Sanhedrin of the Babylonian Talmud 56a.)' (Gensler 2013:78).

- Jesus (ca. 4 BC-27 AD): 'Treat others as you want to be treated, for this sums up the Law and the prophets (Matthew 7: 12)' (Gensler 2013:78-79).

- Muhammad (610): 'None of you is a true believer unless he wishes for his brother what he wishes for himself (Bukhari 1: 2: 12; Muslim 1: 72f; An-Nawawi 13)' (Gensler 2013:80).

\section{Globale etiek as dialektiek}

Dit is belangrik om op te merk dat hier van gedeelde waardes sprake is en nie dominante waardes nie. Studies wat die verskynsel van globalisasie, asook die globalisasie van etiek bestudeer, toon aan dat daar 'n dialektiek tussen die globale en die lokale bestaan (Kirby 2006; Kymlicka 2007). Die ontwerp, ontwikkeling en realisering van 'n globale bio-etiek moet dus nie as 'n dominerende eenrigtingproses beskou word waarin die globale die plaaslike oorheers nie. Verskeie plaaslike gebeure word deur gebeure op 'n groot 
afstand gevorm, terwyl globale gebeure somtyds deur 'n plaaslike konteks en omstandighede beïnvloed word. Globalisasie is nie 'n proses waarin die een globale kultuur die plaaslike kultuur oorheers nie; daar is geen antitese tussen globale en plaaslike nie. Inteendeel, beide kan by mekaar baat vind. In plaas daarvan dat die plaaslike sfeer onderdruk word, bied die opkoms van 'n globale morele raamwerk 'n geleentheid vir universele uitdrukking. 'n Verskeidenheid van inheemse bevolkingsgroepe wat in hulle eie lande benadeel is, het hulle posisie verander deur 'n beroep op menseregte op 'n globale platform te doen. Die idee dat 'n globale bio-etiek 'n koloniserende krag is, neem nie die interaksie tussen die globale en plaaslike in ag nie, maar onderskat die krag van 'n plaaslike waardestelsel (Ten Have \& Gordijn 2014:13-14).

Alles hang daarvan af hoe globalisasie gesien word. Indien dit as 'n onkeerbare proses beoordeel word wat die plaaslike omvorm, vermink en omkeer, is die mens in alle waarskynlikheid aan eksterne kragte uitgelewer wat moeilik is om te identifiseer en te beheer, die plaaslike kultuur homogeen maak, alle identiteite en waardes transformeer en iets is wat slegs verduur kan word. In hierdie sin is 'n globale bio-etiek waardes en beginsels wat universeel bestaan met die doel om plaaslike waardestelsels te domineer. Indien die globale en plaaslike dialektiek egter ernstig opgeneem word, kan globalisasie as globalisasie van onder af beskou word. "What we understand to be "global" is itself constituted within the local; it emanates from very specific agencies, institutions and organizations whose processes can be observed first-hand.' (Burawoy 2001:150) Globalisasie is daarom nie iets wat passief ontvang of ervaar word nie, maar iets wat alreeds op plaaslike vlak bestaan of geskep word. Ten Have en Gordijn (2014) som dit soos volg op:

\footnotetext{
Globalization is therefore not only experienced passively, but in many cases actively produced by groups of citizens, agencies, and institutions at the local level. In this view, global bioethics does not refer to ethical values and principles that are transcending various cultures or are imposed on them from outside, but global values are produced in interactions with local value systems. The global ethical framework is emanating from the fast growing manifold interconnections between people worldwide. (bl. 13)
}

Dit is belangrik dat daar aangedui word wat nié onder 'n globale etiese konsensus of globale etiek verstaan word nie. Dit is nie 'n nuwe ideologie of superstruktuur nie en wil ook nie die etiek van verskillende godsdienste oorbodig maak nie. Dit is geen plaasvervanger vir die Torah, Bergrede, Quran, Bhagavadgita, gesprekke van Boeddha of die spreuke van Confucius nie. 'n Globale etiek beteken nie een globale kultuur nie en nog minder een globale godsdiens.

Alhoewel 'n globale etiek deur sommige wetenskaplikes bevraagteken word, kan daar sonder twyfel aangetoon word dat 'n globale etiek wel bestaan. Die godsdienste van die wêreld het 'n globale etiek tot stand gebring en tot 'n globale religieuse bio-etiek uitgebou wat in 'n sekere sin as die voorloper van 'n latere politieke globale bio-etiek gesien kan word. Vervolgens sal daar nou aan die tema van globale bio-etiek aandag gegee word.

\section{Globale bio-etiek Bio-etiek se ontstaan}

Daar is reeds aangetoon dat 'n globale etiek binne die religieuse wêreld tot stand gekom het. Vervolgens sal daar aangedui word dat 'n globale bio-etiek inderdaad moontlik is en 'n realiteit binne die wêreld vorm.

Bio-etiek is 'n resente verskynsel wat as tema en wetenskap in alle waarskynlikheid sy belangrike oorsprong in die Weste het (Gracia 2014:31; Ten Have \& Gordijn 2014:5). Die term 'bio-etiek' het in ongeveer die sewentigerjare in Amerika onstaan met 'n wye en 'n nou betekenis. Die woord 'bio-etiek' in sy wye betekenis word vir die eerste keer in 1970 deur die Amerikaanse wetenskaplike, Van Rensselaer Potter (1922-2001), in 'n wetenskaplike artikel gebruik (Potter 1970) en kort daarna in 1971, in sy boek Bioethics: Bridge to the future (Potter 1971; Ten Have \& Gordijn 2014:5-6). In 1973 het Dan Callahan 'n artikel met die titel Bioethics as a discipline gepubliseer (Callahan 1973). Onlangs is daar beweer dat die woord 'bio-etiek' lank voor Potter in Europa gebruik is. Die Duitse predikant Fritz Jahr het die term 'Bio-Ethik' in 1927 in 'n publikasie gebruik (Sass 2008). Die waarde van hierdie bewering is dat die gedagte dat bioetiek 'n Amerikaanse uitvindsel is, effens in verleentheid bring.

As onkoloog is Potter deur kankernavorsing van 'n breër visie van mediese etiek oortuig, omdat die mediese wetenskap (in hierdie geval onkologie) essensieel tot 'n interdissiplinêre wetenskap ontwikkel het. In die bespreking van kanker kan daar nie meer eksklusief op individuele (bv. pynverligting en behandeling) en mediese perspektiewe (bv. selmutasie) gekonsentreer word nie, omdat kanker dikwels met lewenstyl en omgewingsfaktore verbind word. Kanker kan dus nie meer net op 'n individuele vlak aangespreek word nie, maar moet ook op die vlak van die breë publiek aandag kry (bv. die voorkoming van kanker deur rook te beperk). Hierdie oortuiging kry in die eerste aantal hoofstukke van Potter se 1971-boek, aandag (Ten Have \& Gordijn 2014:6). Potter het egter nog wyer as net onkologie of mediese etiek gedink en was van mening dat daar belangriker lewensprobleme in die wêreld is wat moet aandag kry, soos oorbevolking, oorlog, geweld, omgewingsbesoedeling, politiek en die negatiewe gevolge van vooruitgang. Hierdie probleme stel die oorlewing van die mensdom in gevaar en lei noodwendig tot besorgdheid oor die toekoms. Wat nodig is, volgens Potter, is ' $n$ nuwe dissipline wat nie net op die tradisioneel mediese etiek en problematiek gerig is nie, maar op 'n breër wetenskap wat hy 'bio-etiek' noem. Reeds vanaf 1975 het Potter die onderskeid tussen 'mediese bio-etiek' en 'omgewingsbio-etiek' gemaak (Potter 1971:150, 1975:2301; Ten Have \& Gordijn 2014:6-7). In sy breë begrip beklemtoon Potter (1971) dat hy tot die toekoms van die menslike spesie wil bydra. Die rede waarom die toekoms in gevaar is, is omdat die twee kulture in die samelewing, naamlik die wetenskap 
en die menswetenskappe, nie met mekaar in gesprek is nie en hy is van mening dat bio-etiek hierdie gesprek kan fasiliteer (Ten Have \& Gordijn 2014:8).

Uit bogenoemde is Potter se breë begrip van bio-etiek as meer as individuele mediese sake en perspektiewe (dus meer as bloot die huidige) duidelik en word daar verder uitgebrei op die feit dat die lewenswetenskappe en filosofie met mekaar verbind moet word. Die doel van bio-etiek is die kombinering van wetenskap en praktiese filosofie, sodat 'knowledge of how to use knowledge' (Ten Have \& Gordijn 2014:7; Potter 1970:127) ontwikkel word met die oog op die oorlewing van die mens en die verbetering van lewenskwaliteit. Die kennis wat bymekaargebring moet word is aan die een kant biologiese kennis of die wetenskap van lewende stelsels (vandaar 'bio'), en aan die ander kant die kennis van menslike waardestelsels (vandaar 'ethics'; UNESCO 2008a:15 van 71). Bio-etiek is multidissiplinêr; alle dissiplines word betrek in die soeke na idees 'that are susceptible to objective verification in terms of the future survival of man and improvement in the quality of life for future generations' (Ten Have \& Gordijn 2014:7-8; Potter 1970:127, 132) Die uiteindelike produk tussen wetenskap en waardes word 'wysheid' genoem wat die mens sal help om te oorleef en 'n lewe van gehalte te leef (Gracia 2014:31; Potter 1970:127, 132, 1971:1-2; Ten Have \& Gordijn 2014:7-8).

Ongeveer in dieselfde tyd as wat Potter die term 'bio-etiek' gebruik het, is die begrip in sy bestaande betekenis deur André Hellegers (1926-1997) aangewend. Hierdie Nederlandse geneeskundige het met die steun van die Kennedy-familie in Julie 1971 (nagenoeg ses maande na die verskyning van Potter se boek) ' $n$ instituut by die Georgetown Universiteit in Washington opgerig met die naam van 'The Joseph and Rose Kennedy Institute for the Study of Human Reproduction and Bioethics'. Vir die groep is bio-etiek slegs 'n voorsetting, met 'n effense uitbreiding, van mediese etiek wat hoofsaaklik aan mediese sake en tegnologie aandag gee (Gracia 2014:31). Daar word hoofsaaklik aandag vanuit die perspektief van die pasiënt gegee (hoe mediese tegnologie lewe kan verbeter, handhaaf en verleng), slegs op korttermyngevolge van mediese en tegnologiese intervensie (verlenging van lewe) gefokus en geen aandag aan sosiale, kulturele en politieke omgewingsdeterminante van die menslike lewe gegee nie. Geen klem is ook op die verbinding tussen medisyne en gesondheidsorg gelê nie (Potter 1988:1; Ten Have \& Gordijn 2014:8).

In die tradisie van Potter is die term 'bio-etiek' vinnig aanvaar en wyd gebruik; UNESCO (2008a) vat die betekenis van die term soos volg saam:

One profession dealing with life during centuries and millennia, especially with human life, has been medicine. But today there are many sciences and professions working in this field. Therefore, bioethics should not be confused with medical ethics, which is only one of its branches. The field of bioethics is as wide as the facts of life, and its study is divided in many branches, each one with its specificity: Ecological or environmental bioethics, Medical bioethics, Clinical bioethics. (bl. 15 van 71)

\section{Globale bio-etiek se voortsetting} Inleidend

Waar kom die begrip 'globale bio-etiek' vandaan? Globale bio-etiek as tema en wetenskap het in alle waarskynlikheid, soos bio-etiek, ook sy belangrike oorsprong in die Weste. 'In any case, it was into Potter's tradition that the concept of "global bioethics" appeared', skryf Gracia (2014:31). In die tweede helfte van die 1980's word gevind dat Potter die term 'globale bio-etiek' gebruik (Potter 1987:160). Sy idees vind uitdrukking in sy tweede boek, Global bioethics - Building on the Leopold legacy (Potter 1988; UNESCO 2008a:16 van $71)$; in die boek word daar op die breë begrip van bio-etiek voortgebou wanneer Potter aan die ekologiese perspektiewe aandag gee. Volgens Ten Have and Gordijn (2014:9-10), wat Potter se tweede boek in diepte bestudeer het, verstaan hy 'globale bio-etiek' as 'n wêreldwye etiese stelsel wat 'n eenheid vorm en omvattend is.

\section{Globale bio-etiese akkoord}

Soos reeds aangedui, kan 'n globale bio-etiek as 'n noodsaaklike minimum van gedeelde bio-etiese norme beskou word. Dit is ' $n$ basiese konsensus van bindende waardes wat, ongeag die verskille en diversiteit, deur alle kulture bevestig word. Die duidelikste voorbeeld van die onweerlegbaarheid van die bestaan van 'n globale bioetiese raamwerk word gevind in UNESCO se universele verklaring van bio-etiek en menseregte (UVBM), (Ten Have \& Gordijn 2014:13-14; UNESCO 2006). Donnelly (2012) wys daarop dat 172 lande (88\% ratifikasiekoers) teen 2012 hulle tot die ses internasionale kern menseregte ooreenkomste verbind het. Hierteenoor is die UVBM in 2005 eenparig deur die wêreldgemeenskap van 191 lidlande aanvaar (UNESCO 2008b:45), wat beteken dat die verklaring die eerste en tans enigste bio-etiese (politieke) teks is waartoe al die regerings in die wêreld hulle verbind het. Ander invloedryke bio-etiese instrumente van menseregte is óf streeksverwant, soos die Konvensie oor Menseregte en Biomedisyne van 1997, óf beroepverwant, soos die World Medical Association (WMA) se Verklaring van Helsinki in 2013 (Ten Have 2011:69, 75). Globale bio-etiek is op alle mense regoor die wêreld gerig. Die doel van die UVBM is: '[T] provide a universal framework of principles and procedures to guide States in the formulation of their legislation, policies or other instruments in the field of bioethics'(UNIESO 2006:art. 2). Die verklaring het dit reggekry om 15 globale bio-etiese beginsels te formuleer wat deur die wêreldgemeenskap aanvaar is en deur regerings, individue, groepe, gemeenskappe, instellings en korporasies gebruik kan word (UNESCO 2006:art. 1).

Die UVBM is in verskeie opsigte ' $n$ globale of universele etiek (vgl. UNESCO 2008b:16 van 57). Globale bio-etiek beteken dat alle mense as rasionele wesens die vermoë en reg het om eie etiese besluite te neem (UNESCO 2008b:3-5 van 57; Gracia 2014:25-26). Die UVBM as globale bio-etiek sluit ook alle sogenaamde Westerse beginsels van Beauchamp en Childress (outonomie, nie-benadeling, bate en geregtigheid, 
UNESCO 2008b art. 4, 5 \& 10) in, asook die meer nie-Westerse beginsels van solidariteit, sosiale verantwoordelikheid en deling van voordele (UNESCO 2008b:art. 13, 14 \& 15). Hier word byvoorbeeld die kombinasie van mediese en samelewingsetiek gevind. 'n Ander (nie-Westerse) beginsel waaroor die wêreldgemeenskap saamgestem het, is dat kulturele verskeidenheid gerespekteer moet word (UNESCO 2008b:art. 12), maar op so 'n wyse dat die beginsel nie ander etiese beginsels domineer nie. Dit beteken dat 'n gesondheidspraktyk wat menswaardigheid aantas, nie geregverdig kan word deur 'n beroep op die beginsel van respek vir kulturele diversiteit nie. Neem ingeligte toestemming (UNESCO 2008b:art. 5-7) as voorbeeld: Afrikalande het 'n kommunitariese uitgangspunt waarvolgens die groep die probleem bespreek en die gemeenskapsleier die leiding in die besluit neem. In Arabiese lande neem die eggenoot die belangrike besluite, eerder as die vrouens. Ongeag hierdie kulturele praktyke vereis die beginsel van ingeligte toestemming dat die betrokke individu ingeligte toestemming moet verleen. In die toepassing van die beginsel kan plaaslike waardes en norme 'n groot rol speel. In NoordAmerika word die teken van uitgebreide dokumentasie byvoorbeeld vereis, terwyl mondelinge toestemming in Afrika en Arabiese lande aanvaarbaar is en 'n handtekening as 'n teken van wantroue vertolk word (Ten Have \& Gordijn 2014:11, 14-15).

Globale bio-etiek word ook as etiek en verantwoordelikheid begryp wat nie net op lewende mense gerig is wat in 'n sekere tydperk lewe nie, maar ook toekomstige generasies insluit. Die UVBM formuleer in artikel 16 (UNESCO 2006) hierdie globale bio-etiese beginsel soos volg: 'The impact of life sciences on future generations, including on their genetic constitution, should be given due regard.' (Gracia 2014:27) Globale bio-etiek sluit nie net die virtuele mens in nie, maar ook die nie-menslike kultuur. Die UVBM gee hieraan besonder uitdrukking in artikel 17 (UNESCO 2006) wat op die beskerming van die omgewing, biosfeer en biodiversiteit gerig is (Gracia 2014:27; Ten Have \& Gordijn 2014:11). Dit is duidelik dat globale bio-etiek soos dit in die UVBM uitdrukking vind, inderdaad wêreldwyd en omvattend is.

\section{Globale bio-etiek as dialektiese proses}

Daar is reeds daarop gewys dat die opstelling van 'n globale etiek nie 'n domineringsproses was nie en dieselfde geld ook vir 'n globale bio-etiek. Die opstel van die UVBM was die produk van 'n dialektiese proses ('two-level process') tussen die globale en lokale wêreld. Voortdurende dialoog tussen die globale platform (UNESCO) en plaaslike kontekste (kulture, tradisies en godsdienste) het plaasgevind. Die lidlande van UNESCO het ongeveer twee jaar lank onderhandel voordat konsensus bereik is. 'n Verskeidenheid van aktiwiteite het in verskillende lande plaasgevind. Konferensies van deskundiges het onder andere in lande soos Litaue, Turkye, Indonesië en Argentinië plaasgevind. Streekskonferensies is gereeld in Latyns-Amerika, die Arabiese omgewing en Afrika gehou. Deskundiges van verskeie lande het vraelyste ingevul en ook kommentaar en aanbevelings geskryf. Die universele beginsels van globale bio-etiek is die resultaat van onafgebroke en multilaterale artikulasie, oorweging en produksie (Ten Have \& Gordijn 2014:13-14).

Dit is van besondere waarde vir hierdie tema om ook daarop te wys dat hierdie globale bio-etiek en menseregte nie bloot 'n politieke konsensus is nie, maar ook 'n (veronderstelde) godsdienstige konsensus en 'n verdere voorbeeld van 'n dialektiek wat tussen die globale en die lokale bestaan. Al die groot godsdienste van die wêreld is deur UNESCO in die skeppingsproses van die verklaring betrek. Ten Have en Jean (2009:31) bespreek in diepte die voorbereiding en opstel van die universele verklaring van bio-etiek en menseregte. 'n Tweede konsepverklaring is vooraf aan al die lede van die internasionale bio-etiese komitee (International Bioethics Committee [IBC]) gestuur wat in Augustus 2004 in Parys, Frankryk, bymekaargekom het. Hierdie sessie van die IBC is deur ongeveer 250 deelnemers uit 80 lande bygewoon. 'n Belangrike deel van die sessie is aan die aanhoor van verteenwoordigers van verskillende godsdienste en geestelike perspektiewe afgestaan. Sprekers van Islam, Confucianisme, Boeddhisme, Hindoeïsme, Christendom (Rooms-Katolisisme) en Joodse tradisie het deelgeneem (UNESCO 2004:2-3 van 38). Elke spreker het 'n aanbieding gelewer waarin daar op die spesifieke tradisie se perspektief op globale bio-etiek gefokus is en sommige tradisies het ook kommentaar op die tweede konsepteks gelewer. Ten Have en Jean (2009), wat ten nouste by die onstaan en ontwikkeling van die teks betrokke was, gee hulle oordeel oor die godsdienstige gesprek soos volg weer (vgl. ook Ten Have \& Gordijn):

One lesson from the presentations and discussions was that although there are differing moral views, common values can be identified ... In the end official representatives of states, but also of cultures, traditions, and religions, could agree on 15 ethical principles of global bioethics. (bl. 14)

\section{Globale morele gemeenskap}

Uit bogenoemde bespreking is dit duidelik dat 'n globale etiek en bio-etiek deel van die wêreld is en daarom kan daar beweer word dat hierdie verskynsel op die bestaan van 'n globale morele gemeenskap dui. Dit beteken dat die burgers van die wêreld, ongeag nasie, kultuur of godsdiens, 'n eties verantwoorde gedrag, wat op gedeelde waardes gegrond is, teenoor mekaar erken en wil uitvoer. 'Our duties are always the promotion and implementation of values' teenoor alle mense, leer UNESCO (2008a:16 van 71). Hierdie idee van 'n morele wêreldgemeenskap binne die bio-etiek word in die algemeen bevestig deur die aanvaarding van die UVBM en in besonder deur die nuwe beginsel van voordeleverdeling (benefitsharing UNESCO 2006:art. 15). Die beginsel is onder andere belangrik binne die konteks van bioprospektering, waar die opspoor van natuurlike stowwe tot die ontwikkeling van nuwe medisyne kan lei. Verskeie ontwikkelende lande is ryk aan natuurlike hulpbronne en tradisionele kennis van inheemse bevolkingsgroepe word deur Westerse maatskappye ontgin en gebruik om nuwe winsgewende medisyne te vervaardig, sonder dat die inheemse bevolking 
enige vergoeding daarvoor ontvang ('biopiracy'). Hierdie beginsel het nou ten doel om geregtigheid te bevorder. 'n Globale moraliteit impliseer dat burgers van hoë-inkomste lande nie meer onverskillig kan wees teenoor obskure navorsingspraktyke of orgaanhandel in lae-inkomste lande nie, aangesien dieselfde morele waardes en standaarde van toepassing is op die globale gemeenskap (Ten Have \& Gordijn 2014:15-16).

Die globale morele gemeenskap wil universele bio-etiese probleme, wat uit globalisasie voortspruit, aanspreek. Die vrug van globalisasie is die bestaan van globale markte wat nuwe probleme skep, soos orgaanhandel, mediese toerisme, korrupsie en bioterrorisme. Bio-etiese sake soos pandemies, ondervoeding en hongerte vereis gekoördineerde globale beleid en optrede. Gesondheidsorg (filantropiese hulpprogramme) is vandag ook 'n globale verskynsel. Sommige ontwikkelende lande was bang dat hulle van die voordele van die vinnig ontwikkelende en globaliserende mediese wetenskap en navorsing uitgesluit sal word. Hiermee saam was daar 'n groot bekommernis dat internasionale mediese navorsing en gesondheidsorg volgens dubbele standaarde uitgevoer word, sodat mense in die ontwikkelende lande minderwaardige versorging mag ontvang en deelnemers aan kliniese navorsing sonder die nodige etiese beskerming betrokke is. Tradisionele bio-etiese probleme word met nuwe uitdagings gekonfronteer. Dit is vandag praktyk dat kliniese navorsing in ontwikkelende lande gedoen word en hierdie realiteit konfronteer die konsep van ingeligte toestemming met verskillende kulturele tradisies waar individuele besluitneming 'n ongewone konsep is. Volgens Ten Have en Gordijn (2014:11-12) is globale bio-etiek nie 'n selfstandige produk van globalisasie nie, maar het dit spontaan as narratief binne bogenoemde bio-etiese probleme onstaan en wil die globale morele gemeenskap dit bestuur.

\section{Gevolgtrekking}

In die inleiding van hierdie artikel is daar aan die eenkant daarop gewys dat die bestaan van 'n globale bio-etiek as 'n Westerse produk verdaggemaak word, terwyl daar aan die anderkant beweer word dat 'n globale bio-etiek nie pluralisme en kulturele verskille na waarde skat nie. Wat 'n mens ook al deur historiese navorsing mag uitvind oor die presiese oorsprong van die idees wat aantoon dat slawerny en rassediskriminasie verkeerd is, kan hierdie inligting geen invloed op die universaliteit van die genoemde norme hê nie. 'The origin of norms does not affect their universality or lack thereof', skryf Ten Have en Gordijn (2014:5). Dit is interessant dat die ontwikkeling van 'n globale bio-etiese raamwerk pertinent deur die ontwikkelende lande versoek is. Hierdie versoek demonstreer dat globale bio-etiese beginsels nie noodwendig deur ryk en magtige lande op die res van die wêreld afgedwing word nie. Die ontwikkeling kan aan die gang gesit en gedryf word deur lande wat nie so magtig is nie (Ten Have \& Gordijn 2014:14). Uit bogenoemde beredenering kan die afleiding gemaak word dat daar 'n globale etiek bestaan wat deur die aanwesigheid van 'n globale bio-etiek aangevul word.

\section{Erkenning \\ Mededingende belange}

Die outeur verklaar dat hy geen finansiële of persoonlike verbintenis het met enige party wat hom nadelig kon beïnvloed in die skryf van hierdie artikel.

\section{Literatuurverwysings}

Burawoy, M., 2001, 'Manufacturing the global', Ethnography 2(2), 147-159. http:// dx.doi.org/10.1177/1466138101002002001

Callahan, D., 1973, 'Bioethics as a discipline', The Hastings Center Studies, 1(1), 66-73. http://dx.doi.org/10.2307/3527474

Donnelly, J., 2012, Universal human rights in theory and practice, 3rd edn., Cornell University Press, Ithaca, NY.

Engelhardt, H.T. Jr. (ed.), 2006, Global bioethics: The collapse of consensus, M \& M Scrivener Press, Salem, MA.

Gensler, H.J., 2013, Ethics and the golden rule, Routledge Press, New York, NY.

Gracia, D., 2014, 'History of global bioethics', in H.A.M.J. Ten Have \& B.Gordijn (eds.), Handbook of global bioethics, pp. 19-34, Springer Science+Business Media, Dordrecht. http://dx.doi.org/10.1007/978-94-007-2512-6_64

Hollenbach, D., 2003, The global face of public faith: Politics, human rights, and Christian ethics, Georgetown University Press, Washington, DC.

Huntington, S., 1993, 'The clash of civilizations?', Foreign Affairs 72(3), 22-49. http:// dx.doi.org/10.2307/20045621

Jonsen, A.R., 1998, The birth of bioethics, Oxford University Press, New York, NY.

Kirby, P., 2006, Vulnerability and violence: The impact of globalisation, Pluto Press, London.

Küng, H., 1997, A global ethic for global politics and economics, SCM, London.

Küng, H. \& Kuschel, K.J., 1993, A global ethic: The declaration of the parliament of the world's religions, SCM Press, London.

Kymlicka, W., 2007, 'The globalization of ethics', in W.M. Sullivan \& W. Kymlicka (eds.), The globalization of ethics: Religious and secular perspectives, pp. 1-16, Cambridge University Press, Cambridge. (Ethikon series in comparative ethics). $\mathrm{http}: / / \mathrm{dx}$.doi.org/10.1017/СВ09780511498701.001

Lepard, B.D., 2011, Hope for a global ethic: Shared principles in religious scriptures, Bahá'í Publications, Wilmette, IL.

Myser, C. (ed.), 2011, Bioethics around the globe, Oxford University Press, New York, NY. http://dx.doi.org/10.1093/acprof:osobl/9780195386097.001.0001

Nezhmetdinova, F., 2013, 'Global challenges and globalization of bioethics', Croatian Medical Journal 54(1), 83-85. http://dx.doi.org/10.3325/cmj.2013.54.83

Parliament of the World's Religions (PWR), 1993, 'Declaration toward a global ethic', 04 September 1993, Chicago, pp. 1-15, viewed 13 Augustus 2014, from http://www. parliamentofreligions.org/_includes/FCKcontent/File/TowardsAGlobalEthic.pdf

Parliament of the World's Religions (PWR), 1999, 'A call to our guiding institutions', Declaration presented on the Occasion of the 1999 Parliament of the World's Religions, viewed from 13 Augustus 2014, from http://www.parliamentofreligions. org/_includes/FCKcontent/File/CalltoGuidingInstitutions.pdf

Plantinga, R.J., Thompson, T.R. \& Lundberg, M.D., 2010, An introduction to Christian theology, Cambridge University Press, Cambridge.

Potter, V.R., 1970, 'Bioethics, the science of survival', Perspectives in Biology and Medicine 14, 127-153. http://dx.doi.org/10.1353/pbm.1970.0015

Potter, V.R., 1971, Bioethics: Bridge to the future, Prentice-Hall, Englewood Cliffs, NJ.

Potter, V.R., 1975, 'Humility with responsibility. A bioethic for oncologists: Presidential address', Cancer Research 35, 2297-2306.

Potter, V.R., 1987, 'Aldo Leopold's land ethic revisited: To kinds of bioethics', Perspectives in Biology and Medicine 30(2), 157-169. http://dx.doi.org/10.1353/ pbm.1987.0053

Potter, V.R., 1988, Global bioethics: Building on the Leopold legacy, Michigan State University Press, East Lansing, MI.

Sass, H.M., 2008, 'Fritz Jahr's 1927 concept of bioethics', Kennedy Institute of Ethics Journal 17(4), 279-295. http://dx.doi.org/10.1353/ken.2008.0006

Ten Have, H.T., 2011, Bioethiek zonder grenzen. Mondialisering van gezondheid, ethiek en wetenschap, Valkhof Pers, Antwerpen.

Ten Have, H.T. \& Gordijn, B., 2014, 'Global bioethics', in H.A.M.J. Ten Have \& B. Gordijn (eds.), Handbook of global bioethics, pp. 3-18, Springer Science + Business Media, Dordrecht. http://dx.doi.org/10.1007/978-94-007-2512-6_63

Ten Have, H.T. \& Jean, M., 2009, 'Introduction', in H.T. Ten Have \& M. Jean (eds.), The UNESCO Universal declaration on bioethics and human rights: Background, principles and application, pp. 17-57, UNESCO Publishing, Paris. (Ethics series). 
Twiss, S.B., 2011, 'Global ethics and human rights: A reflection', Journal of Religious Ethics 39(2), 204-222. http://dx.doi.org/10.1111/j.1467-9795.2011.00473.x

United Nations Educational, Scientific and Cultural Organization (UNESCO), 2004 International bioethics committee of UNESCO (IBC), 'Eleventh Session International Bioethics Committee Of Unesco (IBC)', UNESCO Headquarters, Paris, 23-24 August 2004, 38 pages, viewed 18 November 2013, from http://portal unesco.org/shs/ en/files/7495/11103874181ReportCIB11_en.pdf/ReportClB11_en.pdf

United Nations Educational, Scientific and Cultural Organization (UNESCO), 2006, Universal declaration on bioethics and human rights, 12 pages, viewed 18 November 2013, from http://unesdoc.unesco.org/images/0014/001461/ 146180e.pdf
United Nations Educational, Scientific and Cultural Organization (UNESCO), 2008a, Bioethics Core Curriculum', Section 1: Syllabus ethics education programme sector for social and human sciences division of ethics of science and technology 71 pages, viewed 18 November 2013, from http://unesdoc.unesco.org/ images/0016/001636/163613e.pdf

United Nations Educational, Scientific and Cultural Organization (UNESCO), 2008b, Report of the international bioethics committee of UNESCO (IBC) on consent, 57 pases, viewed 18 November 2013, from images/0017/001781/178124e.pd

Walzer, M., 1994, Thick and thin: Moral argument at home and abroad, University of Notre Dame Press, Notre Dame, IN. 